Article

\title{
Emmanuel Levinas and Ethical Materialism ${ }^{\dagger}$
}

\author{
Jolanta Saldukaitytè
}

check for updates

Citation: Saldukaitytè, Jolanta. 2021. Emmanuel Levinas and Ethical Materialism. Religions 12: 870. https://doi.org/10.3390/rel12100870

Academic Editor: Malachi Hacohen

Received: 11 September 2021

Accepted: 6 October 2021

Published: 13 October 2021

Publisher's Note: MDPI stays neutral with regard to jurisdictional claims in published maps and institutional affiliations.

Copyright: (C) 2021 by the author. Licensee MDPI, Basel, Switzerland. This article is an open access article distributed under the terms and conditions of the Creative Commons Attribution (CC BY) license (https:// creativecommons.org/licenses/by/ $4.0 /)$.
Department of Philosophy and Cultural Studies, Faculty of Creative Industries, Vilnius Gediminas Technical University, 01132 Vilnius, Lithuania; Jolanta.saldukaityte@vilniustech.lt

+ An earlier version of this article was presented as a paper at a conference on "Levinas, The Material, and Ethics" (2017), organized by North American Levinas Society at Loyola University Chicago, IL, USA.

\begin{abstract}
The article discusses concrete and material aspects of Levinas's ethical metaphysics. Firstly, the paper shows that, in contrast to several alternative modern conceptions of subjectivity, the Levinasian subject is not at a safe distance from the world but involved in it through sensing and "enjoyment" and therefore vulnerability. After that the paper highlights the materiality and concreteness of Levinas's ethical metaphysics, a "deformalization" radically opposed to abstractness. It is precisely owing to the transcendence of the Other that the face is always concrete, always a specific, concrete, material solicitation of aid.
\end{abstract}

Keywords: Levinas; ethics; Other; subjectivity; vulnerability; materiality

\section{Introduction}

Ethical imperatives to be good, to be just, to be responsible, and the like, might sound vague and empty. Everybody "knows" such imperatives, but what do they mean? What concrete actions in everyday life are expected? Does ethics have any substantial content, and how? Put into such a context and such a questioning, the Levinasian imperative of infinite responsibility can also seem without content, another normative ideal, vague but indefinite. Furthermore, Levinas's language of passivity and imperative seems to weaken or even eliminate the independence and freedom of the subject, who is allegedly "persecuted" and "obsessed" by the other and finally becomes a "hostage." This has led certain critics to argue that such responsibility for the other is too abstract, uncertain and empty.

Moreover, from another direction of criticism, is it not the case that infinite requirements and obligations for the other can never be fulfilled. Even if I know my responsibilities, my actions to fulfill them are never sufficient. Therefore, are not my attempts from the beginning doomed to failure? "I am responsible even for the Other's responsibility" (Levinas 1992, p. 99), "infinite responsibility" (Levinas [1961] 2007, p. 244), for the Other "I owe all" (Levinas 1992, p. 89), I "have one degree of responsibility more, the responsibility for the responsibility of the other" (Levinas [1974] 2008, p. 117) and so on. One wonders not only where to begin, but why, since failure is assured. And what is more, it is said, these demands come from "the Other" who also remains too undefined, too abstract: "the infinite is the absolutely other" (Levinas [1961] 2007, p. 49), "the face is abstract or naked" (Levinas 2003, p. 32), face is "an appeal or an imperative given to your responsibility" (Levinas 2001, p. 48), "the best way of encountering the Other is not even to notice the color of his eyes" (Levinas 1992, p. 85), "the face is signification, and signification without context" (Levinas 1992, p. 86), and so on. This sort of language has led some scholars, we mention only Jacques Derrida, Rudi Visker, Alphonso Lingis, Algis Mickūnas, Jean Luc Marion and Robert Bernasconi, to criticize Emmanuel Levinas for being too abstract and losing sight of concreteness. Or, as Lawrence Burns underlines, "critics of Levinas reject the notion that the abstract face of the other can ground ethics and generate specific responsibilities" (Burns 2008, p. 315). On the other hand, scholars such as Roger Burggraeve, Clair Katz, Richard Cohen, Adrian Peperzak, Diane Perpich, just to name a few, offer rather different 
reading of Levinas, underlining not the abstractness but the concreteness of the Other. By supporting the latter position in this paper I am going to show the meaning of materiality in Levinas and how Levinas is justified in invoking the words of Rabbi Israel Salanter that the "material needs of my neighbor are my spiritual needs" (Levinas [1968] 1994, p. 99). For that reason, I will address the alleged criticisms of the Other's abstractness and the abstractness of ethical responsibility by underlining the material and concrete aspect of Levinas's ethics.

\section{Materiality of the Subject}

Materiality in Levinas is first encountered, or first constitutionally encountered, as the materiality of the I, of the subject. In a moment we will examine the sort of subject Levinas's analyses oppose. In a broad sense, Levinas, along with most twentieth century philosophers, contests the concept of the modern or Cartesian subject. To be a modern subject, an epistemological construct epitomized by the Kantian ego, as Levinas indicates in Existence and Existents, "is to be a power of unending withdrawal, an ability always to find oneself behind what happens to one" (Levinas [1947] 2001, p. 42). In other words, the modern subject, always one form or another of a "transcendental ego," is to remain at a safe distance from the world-a "distance" required by scientific or objective knowing. It is an ability to experience without ultimately experiencing, to not interfere, which in the language of willing and freedom means an ability to choose but not to commit. The modern rational subject remains crystal clear, a pure transparence; nobody and nothing can shake its universe of rationality. At the same time, Levinas observes, the ego is tempted by the "ambiguity of a situation in which pleasure is still possible but in respect to which the ego keeps its liberty, has not yet given up its security, has kept its distance" (Levinas 1994, p. 34).

The Levinasian subject, quite to the contrary, does not originate in such a safe distance from the world, but is always already deeply involved in it: first, as the very sensing of its sensibility, and second, in the compelling obligations of its ethical responsibilities. In neither case is materiality transcended, not for knowledge, as objective rationality, and not for subjective freedom, as pure choice. The subject in Levinas emerges and is distinguished from anonymous being as an enjoyment of the world at an elemental level of sensing. Such a beginning or origin is not the rational subject but, to invoke a traditional opposition, is empirical. Levinas explicates it in Existence and Existents and, with far more refined analyses, in the Second Part of Totality and Infinity. Owing to the initial instability of such sensibility as sensing, such a subject must also dwell, labor, represent, and otherwise. It finds itself across worldly engagements of greater solidity, as it were, greater endurance and sustainability. The original non-intentional structure of sensibility as "enjoyment" "enjoying" warmth or wet on skin, colors and lights through vision, bitter and sweet as tastes, etc.-entails the irreducibility of corporality and material needs for subjectivity in its worldliness. So Levinas argues that before knowing or using the world, I enjoy the world. Contrary to the phenomenological claims of Martin Heidegger, then, who sees the world originating as a network of tools and equipment, as the "ready at hand" subtending knowing or the "present at hand," one first enjoys. Things not only refer to their way of use, their interconnection in an instrumental complex, or the structure of the environment and the world, but first of all are sensed, felt, touched, heard, not even as object or things, but as warmth, cold, wind, blue, and so on. Enjoyment is not only before theory but before practice as well, as the condition for both. I find myself in the world bathing in its "elemental" "qualities" - without substances—and then, owing to their very insubstantiality, having to take care of my own body, or really being taken care of (hence "dwelling") —eating, drinking, dressing, looking for shelter or rest, and so on. We emerge in the world and depend on the world by having material needs, and as such, based in the materiality of our bodies, we are subjects of material needs. From such an elemental beginning we survive in a world, of dwelling, construction, representation, and their like. 
It is crucial to notice that in Levinas's philosophy, enjoyment of the world and things shows that enjoyment comes not from spiritual but from carnal things. Philosophical tradition all along (just with few exceptions, such as some Aristotelians, Epicureans or Hedonists and later phenomenologist) dismissed this human condition and interpreted the body as "prison," as chains, looking for ways to liberate the human mind and spirit, or seeing in the mind precisely liberation from such carnal destitution and confusion. In Levinas's philosophy we do not see that. Bodily connection with the world is joy or pain of breathing, watching, eating, flexing muscles, holding a hammer, and so on. I am not free here to choose: it is not I can, but I undergo, I am involved in the world, and as such, having a body, I am inescapably already captured in the "suffering" the real, pleasure or pain. I live in passion. Such is the passivity of sensitivity-which receives another meaning in the ethical stage.

This fundamental deep level of sensation cannot be represented or reached by intentional consciousness. Or rather, its representational or intentional analyses must not be confused with its original non-representational and non-intentional character. "We live from "good soup," air, light, spectacles, work, ideas, sleep, etc. These are not objects of representations. We live from them, and through them. Nor is what we live from a "means of life," as the pen is a means with respect to the letter it permits us to write-nor a goal of life, as communication is the goal of the letter" (Levinas [1961] 2007, p. 110). Some call it "material phenomenology of subjective life" (Critchley 1999, p. 271). Material phenomenology, as it was understood by Michel Henry, is rooted in pure and radical immanence prior to any subject-object division ${ }^{1}$. Objective representation, as Levinas argues, ignores the "specific intentionality of concretization" (Levinas [1961] 2007, p. 153); its decisions come only a posteriori. Such knowing claims about the world are made as if they were beyond it, ignoring the fact that consciousness is always interwoven, from and through the world. The reference to a non-intentional layer, which we find in Levinas, forces an expanding or overcoming the absoluteness of Husserlian phenomenology.

Enjoyment is naïve and innocent, as Levinas suggests in Totality and Infinity. It is "happy," in the sense of "carefree." Nevertheless, despite the positive side of enjoyment, this kind of material existence appears to a more complex and differentiated account as indifference and exploitation of the other. For hedonistic moralities, there is nothing beyond satisfaction. What matters is the satisfaction itself, and as such enjoyment remains selfish. The subject is self-contained in self-satisfaction-deaf and blind-for the other and, therefore, situatedness within totality is not really ruptured, disturbed, in relation to alterity, or so hedonism promotes. Such a self and selfhood, however, is constituted but not yet "fully human". Contemporary society, in many cases, hovers here-in hedonistic morality, chasing after some new and unknown pleasure as one of the most significant aspects of life today. Enjoyment of the world, the many self-satisfactions to be had in the world, might turn into an eagerness to try and to experience everything. This temptation of temptation includes, but is not limited to, enjoyment or materiality and leads to an aesthetic path, which has its spiritual as well as its empirical fruit.

Nevertheless, pleasure, enjoyment, as subjectivity is already separated from the initial materiality and brings to the other side of being, which Levinas calls "first morality" ( Levinas [1947] 2005, p. 64). In enjoyment the subject has already escaped or transcended the anonymity of what Levinas calls the "il y $a$ "- the "there is," measureless indistinctness or anonymous being. It indicates that the subject is not only embodied in the world but that the structure of enjoyment already breaks with totality (escapes il-y-a). Enjoyment is thus an "act" —or rather a sort of passion—of separation which is the deepest sense of the principle of individuation and independence: "The interiority of enjoyment is separation in itself, is the mode according to which such an event as separation can be produced in the economy of being. Happiness is a principle of individuation, but individuation in itself is conceivable only from within, through interiority" (Levinas [1961] 2007, p. 147). It is not only an escape from anonymity, but also the condition for ethical subjectivity and metaphysical relation. Enjoyment might be interrupted, and the subject might find himself 
vulnerable. No baby born can survive on its own. Levinas already in the article On Escape, 1935, indicates the "insufficiency of the human condition" (Lévinas 2003, p. 51), which is not reduced only to the question of being. More profoundly, it shows that the other is exposed, is vulnerable as well.

Such an approach, acknowledging human weakness and finitude, human dependence, remarkable for its originality in the history of philosophy, has, of course, provoked counterclaims. For example, Tom Sparrow, quite provocatively, having recognized Levinasian engagements with the world and the rise of the subject through alimentation and nourishment, calls it a "corporeal ontology" (Sparrow 2015, p. 63) and argues that "Levinas provides an account of the body which overstates the vulnerability of the body and obscures the enabling effects of sensation" (Sparrow 2015, p. 66). Sparrow acknowledges the novelty of Levinasian notion of sensibility and vulnerability but at the same time criticizes him: "emphasis on the vulnerability of the body—that is, its susceptibility to wounding or its openness to the outside-goes too far in its appreciation of the reality of violence" (Sparrow 2015, p. 143). Here Sparrow has appropriated to endorse his teacher Lingis's criticism of Levinasian mortal vulnerability as a "fundamental mistake" (Lingis 2009a, p. 164). According to Lingis's reading, Levinas envisions humans (and animals, all forms of life, for that matter) negatively, as lacking. Although in an earlier article "Sensuality and Sensitivity" (1996), Lingis had acknowledged Levinas's account that "sensuality is vulnerable and mortal from the start" (Lingis 1996, p. 80), later, in what seems like an about-face, to make mortality, he argued that vulnerability, finitude the defining essence of human existence is but a continuation of an ancient error. This clarifies how Levinas's and Lingis's positions differ: to claim that body is the "prison" and to underline the vulnerability is not the same. If body is the chains, the prison, we want to overcome it, but if we see that human life is embodiment and the body, unavoidable, is vulnerable, we have to deal with it. For Levinas that is the possibility for ethics, for social relations between humans. So what is crucial for Levinas is to show how the ethical arises, while Lingis wants to turn away from the ethical, and does so by leaning on the aesthetic. Aesthetic here means not only sensing and admiring beautiful things but making this a priority, putting such sensing above ethical responsibility. Therefore, it is not neutral, and paradoxically proposes an ethics of non-ethics, the raising of aesthetics above ethics. The encounter with Other in their philosophies therefore has an entirely different meaning, a difference to which we will return shortly.

\section{Paradox of the Abstract and Concrete Other}

The Other in Levinas's philosophy does not appear directly: s/he is encountered as face. There has been much discussion in the secondary literature on the "face of the other" and interpretations vary from trying to describe face as concrete or as abstract.

Traditionally in the history of philosophy, abstractness is the opposite of concreteness and specificity: like an individual chair in relation to the "idea" of chair, each concrete person is said to never fulfill the idea of a human being. The idea of good only partially participates in concrete actions or objects; the idea of justice is not fully implemented in just acts. Following this logic, whose roots are at least as deep as Platonism, many readers took it for granted that we only recognize an abstract other in Levinas's philosophy but never the concrete and individual other. In other words, it would be as if the Other or the Face is another name to substitute for idea, God or Being. When Levinas claims that in relation with the face appears the idea of infinity and "the infinite is the absolutely other" (Levinas [1961] 2007, p. 79), it makes the reader wonder if we still can find here the concrete other. His critics claim that by introducing the idea of infinity we lose direct experience of the world and intersubjectivity, and therefore lived life, and philosophy itself, are denied. According to their arguments, which echo those of Kant centuries earlier in another context, infinity cannot be experienced but only postulated. It is but a "speculative leap" to infinity and the infinite other, which by essence are alien to philosophy. Some critics, Mickūnas (Mickūnas 2011) among them, argue that going beyond ontology 
and beyond phenomenology, as Levinas explicitly does, can only mean falling back into theology or speculative metaphysics.

For example, as keen an interpreter as Robert Bernasconi agrees that in Totality and Infinity Levinas invokes the face as the concretization of the Infinite, but at the same time, he argues, Levinas "shows little or no interest in the concrete Other, but aims instead for an abstract Other" (Bernasconi 2000, p. 83). To elaborate this criticism, we may take a closer look at Jean Luc Marion's reading of Levinas which is a good example of such an approach. In his article "From the Other to the Individual," Marion argues that the face of the other remains anonymous: "it appears as "no person," as no individual, as no so-and-so, it does not appear, to sum up, in person, nor as a person. With the Other, no person appears yet" (Marion 2005, p. 108). Marion presents three arguments to prove such a reading. First, all principles are applied universally, for all other Others, without exception or giving priority to some others: "the poor, the foreign, the widow and the orphan remain themselves as yet indistinct, with no name, and no individuality. ... We are dealing with anonymous, even unknown "givees", and they must remain so in order for the prohibition to issue" (Marion 2005, pp. 108-9). Second, because a face is without context here, Marion claims, there appears a certain duplicity. Face cannot reveal its ethical situation, and, therefore, the gaze of the victim might be confused with his persecutor or an impostor's face. Marion argues that in this way "the banality of evil finds its place in the anonymity" (Marion 2005, p. 109). Third, even though Levinas says that "separation is the very act of individuation" (Levinas [1961] 2007, p. 299), Marion finds that such words are not enough to prove that individuality arises. Traditionally, the subject's identity is strongly connected to essence: as if the subject unfolds and becomes as it is supposed to be. As Levinas, unlike Aristotle, goes beyond essence, it remains unclear-or so Marian believes-how, without having recourse to essence, an act can individuate. Even if somehow it may apply to I, ego, still, the individuation of the Other does not occur. So, "the Other thus appear as "no person," ... , he appears as no individuated person, only playing the character (persona) of each possible Other" (Marion 2005, p. 110). Furthermore, as Levinas argues that "in the concreteness of the world, the face is abstract" (Levinas 2003, p. 32), Marion claims that the particular alterity of a particular Other does not appear as "the face does not take into account persons, it is the face of no person" (Marion 2005, p. 110). To sum up, according to this interpretation, Levinas failed to break with the philosophy of Neuter, despite his own criticisms of such a philosophy in Totality and Infinity, as it triumphs in the anonymity of the face. So, it is seen that the face of the other, as well as the Other, remains abstract, neutral, and anonymous. The face of the other is not experienced as a phenomenon; Other is not identified.

We can identify one of the most common mistakes in these readings: as if the singularity, otherness, alterity can be described by quantities. While talking about the Other, we are always tempted to talk about the far-away one who is strange, weird, bizarre, who is not only the other but who is necessarily (or preferably) different in an extraordinary way. Moreover, it is suggested, the Other must also have his essence, which might be captured by describing and cataloging it. Visker, for example, by trying to solve this tension between abstractness and concreteness, thinks that, in order not to be reduced to these features, one has to be detached from it. "What if,- - he asks, - the other refuses to be just another (an Other) human, and insists on being a woman, on being black, homosexual...?" (Visker 2004, p. 181). As if the Other can only be the other without qualities, without a body, without a gender or name. Lingis, too, claims that alterity in Levinas is "a fundamental ontological category" (Lingis 2004, p. 21). However, it would be a mistake to think of alterity as an attribute. The otherness of the other is not a function of weirdness, peculiarity, a tic, a pimple, a skin color, and the like. The otherness of the Other is not like a fingerprint or snowflake, except insofar as it is treated as a spatial-temporal object like any other, and differentiated like each and every spatial-temporal object. The otherness of the Other in Levinas does not fall into these categories.

It must be noted that the other does not refer to specific differences but rather to singularity. In other words, even if the face is not a plastic image, even if I "do not see the 
color of the other's eyes" (as critics so often repeat, getting the sense of Levinas's claim wrong each time), the face is always concrete and not interchangeable. For Levinas the face is given empirically, it is a "body expression" (Levinas [1961] 2007, p. 258), but at the same time, it breaks from its context: it is not a surface but an expression. The face is abstract, not in the sense of empty, intellectualized, but without context, deeper, more demanding than any context, and as such it "enters into our world from an absolutely foreign sphere, that is, precisely from an absolute, that which in fact is the very name for ultimate strangeness" (Levinas 1987, p. 96). So the face, while being is concrete, this or that face, is "abstract" inasmuch as it is more, a surplus over its own genus and species, its relative differences. It's otherness is not relative but radical and absolute. When Levinas says that the "idea of infinity" is encountered in the face of the other, it does not indicate that the face is eidos, purified from all concreteness, materiality, corporality. In other words, even if the face is not a plastic image and radical alterity cannot be reduced to materiality of the face, the materiality of face intrudes, meeting the other as belonging to some race, some gender, some age, and so on. In the materiality of the face, of the body, is inscribed a particular cultural-social context even if in no way is the otherness of the other reducible to its context. The orphan, the widow, the stranger might be a metaphor, but it is not only a metaphor. These "figures of speech" refer as well to the concrete person, the one who faces, in flesh and blood, this face, You. The idea of infinity is the social relationship (Levinas 1987, p. 54), but not epistemological or theological. It is this conjunction which makes for singularity that critics seem to want to separate out into universals and particulars, or reduce to one or another context (language, being, gender, culture) to deny its uniquely compelling imperative grip.

In answer, no doubt for Levinas, meaning comes from transcendence, from the irreducible otherness of the Other, but only and always as deriving from concrete situations. ${ }^{2}$ By agreeing that the irreducible transcendence of the other person is the main point of Levinas's ethics, I want to underline-in contrast to such critics as we have already invoked - that this does not mean a denial or rejection, or underestimation of concreteness and particularity.

\section{Vulnerability of the Other: Deficiency and Surplus}

The encounter with the other is not mysterious and enigmatic; but neither does it occur at the self-conscious or rational level. The face is an expression, and this expression has an irreducibly ethical meaning: the Other is not (only) strange; the other is Other in his vulnerability, and the face of the other is begging my help, the face is saying: "do not kill." It is vulnerability, disturbing me as solicitation. The other affects me with the possibility of material poverty, expecting from me help, a help that depends on material proximity to his suffering. Like Merleau-Ponty's "flesh of the world," ethics arises in the proximity of two persons, both of whom suffer (including enjoyment) from vulnerability. Not only in the vulnerability of the other as embodied, but of myself as embodied as well. This does not make self and Other equal however, but indicates how one person can help another. The Levinasian imperative- the call to take responsibility for the Other-comes not from the abstract but from the concrete face of the other, from the other's suffering, which I already "understand" because I too am vulnerable, embodied, a suffering. That is, it arises in and across materiality. Materiality here is not abstract-as matter-form, res cogito-res extensa dualism nor it is some form of historical materialism. It is a real and concrete embodiment. Inter-subjectivity originates in the inter-corporeality arising from the sensibility's exposure and vulnerability, from wounds, illness, pain, exhaustion, and aging. Material, body, comes first because the other's vulnerability, all the way to mortality, comes first. Some critics, as it was mentioned above, argue for rejecting bodily vulnerability and suffering — and ethics—as the essential terrain for human relation, and hence for philosophy. Instead, following Friedrich Nietzsche and certain Christian and Hindu mystics, Lingis, for example, underlines the joy of life. The joyousness of life, the energy of life, the excess of that energy is what signifies our condition, but not suffering. 
He believes that taking the alleviation of suffering to be essential is to continue an ancient error. Contesting Levinas, Lingis claims that when other faces us, we see the life, the smile, the achievements, what the Other made with and of himself and his life but not his vulnerability: "When others greet us and call for our attention, our attention is turned to the force of life in them, which has grown and striven - the force of an individual life. We see a life that enjoys living, that finds goodness in living. We find ourselves called upon to let this life be, to respect its space, to let it flourish, to care about it and care for it. We see facing us someone in whom nature has achieved something: we see hale and hearty physical heath and vigor, vibrant sensibility, beauty" (Lingis 2009a, p. 165). For Lingis, encountering the goodness of life means the joy of life as what is most empowering. "Is it only his or her suffering that appeals urgently to us, has importance, and afflicts us immediately? Is there not always joy in the one who faces us, even joy in his suffering - the joy of finding us?" (Lingis 1999, p. 398).

Lingis's criticism and longing for the happy face indicate one of the main differences separating Lingis from Levinas, or different readings of Levinas in general. The expression of the face, so crucial for Levinas, of course, might be joy or anguish. However, it is a vulnerability which, for Levinas, is the condition for ethics, while joyousness of life leads to feast, self-affirmation, triumphalism, all the aesthetics of irresponsibility, which in our day has become an entertainment industry, the "me first" generations. As mentioned above, Levinas foresees this diversion but, for him, the epicurean life of enjoyment, succumbing to the non-ending temptation of temptation, shirks what is most human about the human, namely, the humane. He sees it as lacking, fundamentally, but lacking also not because it is joyful, rich, but because it is destructive and cannot last, on the one hand, descriptively, because humans are vulnerable and enjoyment is fragile, but on the other hand, imperatively, because it remains caught up in the small circle of selfishness, self-absorbed and self-enclosed like a Moebius strip. Say what it will, celebrate however it can, it produces and relies upon the exploitation of the other, the one who suffers, and ultimately all humankind in its suffering and destitution. Philosophically, Lingis has substituted or inserted the idea of lack where Levinas would speak of desire and the Desirable. For Levinas the suffering of the other disturbs my enjoyment, and this disturbance is not a lack but a call awakening in me my non-substitutable responsibility for-the-other. The other's hunger becomes my responsibility. To aid the Other is no lack in the self, but to rise to one's proper height, one's responsibilities. Not for one's own sake, to be sure, but in the course of helping the other: such is infinite obligation, to always do more. The vulnerability, the suffering of another human being puts the subject into question, and being put-into-question is the very height of our humanity. In a recently published book, Eric Nelson in Levinas, Adorno, and the Ethics of the Material Other underlines that "Needy, wanting, imperfect life in its incompletion is not only necessary for the desire for the good, which, as disinterested and non-indifferent, surpasses being determined by hunger or need to the point of giving the other one's sole piece of bread, but is the locus of the alterity of ethical transcendence within worldly material immanence" (Nelson 2020, p. 11). The vulnerability of the Other is seen then not as a human deficiency but as a call for responsibility, the possibility to overcome one's own limitation.

Critics of Levinas, even when they recognize the inordinacy of Levinasian responsibility, denounce it for this very reason, saying it cannot be accomplished, is too overwhelming. This is perhaps the most classic criticism of ethics, the voice of "is" attempting to silence the imperative "ought": it is too much, we cannot succeed, so we will do nothing. Here we again find Lingis, among others, rejecting the Levinasian call as "this teaching cannot be the basis for effective actions. My abilities and my resources are limited" (Lingis 2009a, p. 166). It demands too much, so I will do nothing! I don't have enough resources, so I will donate none! These are the perennial rationalizations of the rich against the poor, the strong against the weak, the victors against the vanquished. One form of this general refusal of ethics is epistemological. Lingis agrees that the face of the other is concrete and empirical, that the Other's demand is not a theoretical construct, and response must be a 
material response. However, he disagrees that we know what the other needs: "But may not the suffering I see well be a suffering that does not seek to be consoled?" (Lingis 1999, p. 398). Invoking it, however, Lingis suggests that, at first, we should doubt the suffering of the other. Maybe it is not suffering at all; maybe the other might not need our help after all? Elsewhere: "We just understand that the other may need and want his suffering, in perusing his destiny" (Lingis 2009a, p. 168) ${ }^{3}$, that his or her bleeding and broken arm wants to continue bleeding and be broken. Undoubtedly, suffering is part of growing and self-development, but that-and all of these particular instances-does not eliminate the Levinasian imperative. Nothing, in fact, could be a more callous or blind rationalization: oh, the poor suffering ones, the hungry, the cold, the sick, yes, they want to suffer, they enjoy their suffering, and we shall wash our hands, leave them be, for their benefit. One does not let suffering be, because it is wrong, painful, even if the other, in an exceptional humility, would prefer that yet other sufferers should be helped first.

We do agree that we cannot know the other, that $\mathrm{s} /$ he remains an enigmatic but elevating suffering imperative and non-negotiable. But this is to say that the encounter with the other occurs not on the epistemological level but at the ethical: it is "welcoming" not at first knowing, representing, cognizing. Lingis criticism of Levinas follows from his affinity to Nietzsche and therefore he can say that "Contact with the other in his vulnerability and mortality can produce the pity that is simply the contagion of misery and debility. And the simple impulse to help, to supply, to cure of itself contains a will to power" (Lingis 2009a, p. 167). So ethics would be but a form of "will to power," even if weak and sick, as Nietzsche believes. In view of this interpretation, alternative ethics, denying the name ethics, however, is found attractive by many postmodernist thinkers, tempting us to admire suffering faces but not to alleviate the suffering. Thus the ethical is reduced to an aesthetics, a spectacle. This recalls the debate surrounding the infamous photograph "The Struggling Girl" (1993) taken by Kevin Carter: what do we choose-to help the starving child without calculation or to wait for a good angle to take a more powerful picture? In the latter case the suffering is taken not ethically but aesthetically. Besides, pursuing such a view, Lingis proposes the notion of "tact," taken from what are considered good manners in high society, which is "a sensibility for the susceptibilities and sensitiveness for another," which "consists in finding the right touch, the right words, the right tone, or the right silence when facing the another" (Lingis 2009a, p. 167). Too delicate, too sensitive, too reticent, however, to intervene and help. Alternatively, then, to express this same tact in other words, we may say, the triumph of bourgeois politeness, minding your own business: "In fact tact that holds back one's forces and intentions is a supremely sensitive form of receptivity" (Lingis 2009a, p. 167). What is unsaid in all this hypersensitivity is that it justifies "doing nothing," not only putting aesthetics but a specific bourgeois (miming aristocratic) etiquette above ethics. It mimics also Heideggerian Gelassenheit, "letting be", which, as we know, brings close not the Other but the initiative attributed to Being. But such a position does not remain neutral. Does not such a posture rather fulfil the Christian theological idea of purifying pain and anguish, of theodicy, or what in today's parlance we might call "blaming the victim?" Levinas captured the contagious of embodiment, vulnerability, mortality and suffering, beyond the boundaries, that is to say, of bourgeois liberal individualism, however glossed in postmodern sensitivities.

\section{Other Material Needs as My Spiritual Needs}

The vulnerable and suffering body of the other disrupts the identity of the subject, his egoism, interrupts his enjoyments. Here, an egoistic enjoying subject is transformed into an ethical subject, he not only, as we like, is singularized but is so as an election, chosen, a hostage, a responsibility before all else and before all others, including oneself. He is not the isolated ego, not will to power, but obligated, in relation to the other. The responsibility is on my shoulders, and it cannot be transferred to anyone else-this testifies to the uniqueness and specificity of the chosen subject. Here, beyond the borders of what is always only an abstract liberal individualism lies the more pressing weight of ethical 
singularization in responsibility. If the enjoyment closes the subject from within himself and makes him indifferent to the other (that is, the topic of Totality and infinity), suffering from the pain (which is more developed in Otherwise than Being or Beyond Essence) brings us closer to others. Such ethical responsibility does not come from obedience to the canons of Catholic morality, arises not because of rational calculation and the Kantian imperative. What matters, the alterity that exerts its pressure, as it were, is the other's vulnerability and need for help. What singularizes both, the other and myself, is moral exigency: the other person as concrete materiality, vulnerable body, and I, and I alone, am the one who must provide: the other might need food, shelter, medicine, interlocutor, money, or company. Responsibility for the Other is here and now, in a concrete situation. By describing the other as weak and naked, what is underlined is not spiritual suffering but bodily pain. The suffering, pain, is not only a metaphor, just as "violence" is not only a metaphor. It would be evil to transform it to metaphysical abstraction or put on it a romantic-mythic or, alternatively, a purely spiritualized gloss. It is concrete, material pain, bodily weakness. Suffering is always concrete suffering of this or that person. It is not universal. ${ }^{4}$ The body, which is exposed to violence and injury, disease, old age, fatigue, is the body's real nudity. As such, suffering is manifested as a self-enclosure, a being closed in on itself, an infinitely passive suffering without the ability to escape. Physical suffering, unlike so-called spiritual ills, does not sustain human dignity and majesty. "The pain," says Levinas, "this underside of skin, is a nudity more naked than all destitution" (Levinas [1974] 2008, p. 49). The suffering of the sufferer is experienced as meaningless, in no way positive, but only negative. It is, as Levinas underlines, "useless suffering." Justification of the Other's pain, all the way to theodicy, is the source of immorality. It is not abstract evil as such; it is not a threatening monster but a concrete suffering without romantic gloss. For Levinas corporal suffering of the other is always evil, and it has no meaning and justification; it cannot be forgiven. Here this suffering of the other is more important, and it is necessary to take care of it first in order to alleviate this suffering.

The Levinasian imperative to be good, to be responsible is mistakenly seen as an uncompromising categorical imperative, as the Kantian law of morality applied universally but not specifically and concretely. Kant might have to be seen as the closest thinker to Levinas, as Richard A. Cohen has underscored, but this refers to the primacy both philosophers accord to ethics, even if Kant, unlike Levinas, remained bound to a theoretical reason still detached from the concrete and singular ${ }^{5}$. We should remember that Levinas is not creating a moral system, or rules and orders. Instead, as both a phenomenologist and philosopher of ethics, he is unveiling our condition in the world, whose significance is fundamentally ethical. For a theoretical orientation, the particular must obey the universal rule, which ties both to a specific modern form of representational rationality. The Kantian imperative seeks universality while the singularity of Levinas's responsibility is not originally a matter of universals and particulars, form and content. Lingis, however, like Marion, criticizes Levinas for the Kantian argument he did not make. In Levinas's ethics, responsibility is not separated from the concrete relation with the Other. Every encounter with the Other occurs in particular time and space, in particular conditions, but is not fundamentally determined by rational causality or motivation, or a "pure freedom" designed to escape determinism.

The universal imperative is rephrased, as it were, into a concrete imperative; it starts in the concrete encounter with another suffering body, the face of the other. The source of ethics is not autonomy but heteronomy. The ethical commitment goes beyond the power of the subject and its intentional nature, even when the latter is conceived phenomenologically. Here the direction of intentionality is reversed-I am not the initiator, not the absolute or transcendental ego, but the other person calls and persecutes me despite my "tact," which is simply a more refined form of escapism, of refusing the other, the source of all evil. I do not choose to be responsible; I am called to and for it: "The responsibility for the other cannot have begun in my commitment, in my decision" (Levinas [1974] 2008, p. 10), it goes against the subject's will. Not in synthesis or activity, but in passivity is the ethical subject "constituted." The unbearable burden of infinite responsibility does not go away, even if it 
must also be adjusted by the necessity to establish supportive social institutions, i.e., at the political level. Thus, the ethics of Levinas is not the denial of the materiality of the world, nor pure hedonism, but the return to the material needs of others, to concrete fulfillment for the other.

Often in literature, or even in religious movements, material needs (body care, food, clothes, asylum) are approached negatively, they are considered lower, and too much care is even somewhat shameful. Certainly, we can agree with the intention of such a protest if it becomes true that we lose sight of the difference between providing comfort and a luxurious life, between help, that is to say, and exploitation through selfishness. We certainly are not blind to the difference between spiritual and material needs, but we must recognize, too, that the Levinasian ethics is not established following this difference, indifferent to one or the other or both.

In Levinas's ethics, even when his texts talk about transcendence, the infinity of the Other, the infinite responsibility for the Other, the materiality and concern for corporeality are not rejected or dismissed for so-called higher spiritual goals. The relationship between ethics and corporeality (as well as spirituality and materiality) is emphasized by Levinas, saying that "The incarnation of human subjectivity guarantees its spirituality" (Levinas 1992, p. 97). The angels, the disembodied beings, are not injured or disturbed, and, says Levinas, I do not see what they can give or how they can help each other. In the Jewish tradition it is said the Torah of Mount Sinai is given to humans, not angels. Angels do not go hungry or keep kosher. So true spirituality is not between spiritual or robotic beings but between physical, fleshly, worldly beings. Both the other and the I are physical, corporeal, and the relation to the other is universal, concrete, embodied. Only incarnate creatures, vulnerable and mortal ones, are subject to an ethical requirement, and only as embodied beings can it be answered. Only the one who enjoys can be for the other, to recognize the pain of another: "Only a subject that eats can be for-the-other, or can signify. Signification, the-one-for-the-other, has meaning only among beings of flesh and blood" (Levinas [1974] 2008, p. 74).

The immediacy of sensibility, the closeness of proximity, says Levinas in Otherwise than Being, is my materiality for the Others (Levinas [1974] 2008, p. 74). The other who is appealing to me always is unique and concrete, and he needs something. That is why my answer must as well be concrete, "economical." Cohen, in his recent book Out of Control: Confrontations between Spinoza and Levinas, underlines that for Levinas, "Morality is carnal rather than ethereal. The demands of the other are concrete, real, particular. The other's suffering becomes my own suffering: a suffering for the other's suffering" (Cohen 2016, p. 54). Unlike endless desire, unlike enjoyment or lustful spiritual needs, the material needs, as we have already indicated, can be met, and the other, vulnerable, suffering, embodied, is precisely what makes demands upon me, prior to any contract. Contra Lingis (Lingis 2004, p. 27), Levinas does not eliminate the material imperatives. Care for the other must be embodied, material-open the door, feed the hungry, and the like. Good intentions or pure conscience is not enough. From this approach, living in the world is much tenser and tied up than the Heideggerian In-der-Welt-Sein. According to Levinas, as Burggraeve emphasizes, again invoking a Jewish reading, I must love my neighbor not only with all my soul, with all my heart, with all my understanding, but also with all my money (Burggraeve 2002, p. 110). Even more- “'It's not a gift from the heart, but of the bread from your mouth, of one's own mouthful of bread. It is the openness, not only of one's pocketbook, but of the doors of one's home" (Levinas [1974] 2008, p. 74). The subject is "flesh and blood," hungry and eating, and this is why it can allow another person to enter, or rather how I can share my food. Furthermore, as Levinas says in Totality and Infinity, "No human or interhuman relationship can be enacted outside of economy; no face can be approached with empty hands and closed home" (Levinas [1961] 2007, p. 172).

So Levinas draws a distinction not between spiritual and material needs but between satisfying my material needs, selfishly, "tactfully," and meeting the needs of the other, generously, through self-sacrifice. Ethics is to take care of the other-and in no way has to 
do with Heideggerian Sorge. When I take care of myself, I am happy and safe but selfish. So here comes a difference like the difference between my enjoyment of the food I eat and the food I give to another. By making a distinction between my own hunger and the hunger of the other, for Levinas, the latter is a demand of holiness. The only "bad materialism" is our own (Levinas [1963] 1990, p. xiv), and "while one certainly has the right to denounce one's own hunger as materialist, one never has the right to denounce the hunger of others" (Levinas [1963] 1990, p. 165). The material aspect of human being, the material life, touches me, and through another takes on an uplifting meaning and affects my holiness. Because of the other, I become responsible, an ethical subject-starting with giving of food and drink. This holiness is the holiness of a social problem. The problem of food and drink, as it relates to others, is seen by Levinas as sacred (Levinas 2001, p. 52). So, in Levinas's philosophy, it is possible to notice a specific transformation: the "divine" dimension in the return to bodily needs, and corporeality itself. To become a spiritual, "higher" being, you do not have to, and you should not, lock yourself in a cave or cage or sit alone in the desert or a monastery scourging oneself, you do not have to escape the body which is in truth inescapable. Materiality itself, here, before others, paradoxically and against any logic, is the source and object of spirituality, to serve the happiness of the other. Materiality here becomes holiness and defines responsibility.

Funding: This research received no external funding.

Institutional Review Board Statement: Not applicable.

Informed Consent Statement: Not applicable.

Data Availability Statement: Not applicable.

Conflicts of Interest: The authors declare no conflict of interest.

\section{Notes}

1 "This self-givenness [ . . . ] is structurally different from "relating-to". It is not in itself a "relating-to" but insurmountably excludes it from itself. It is not outside of itself but in itself, not transcendence but radical immanence. And it is only on the basis of this radical immanence that something like transcendence is possible. Seeing is actualized only as a nonseeing, by not being related to itself in an act of seeing and by not revealing itself through this and thus as something unseen and invisible. This nonseeing, this unseen, this invisible, is not the unconscious. It is not the negation of phenomenality but its first phenomenalization. It is not a presupposition but rather our life in its non-ek-static but yet undeniable pathos" (Henry 2008, p. 81).

2 Bernasconi asks a similar question in (Bernasconi 1989, pp. 23-34) “Rereading Totality and Infinity" in The Question of the Other: Essays in Contemporary Continental Philosophy. Dallery, A. B. \& Scott, C. E. (eds). 1989. Albany: State University of New York Press, pp. 23-34.

3 Similar criticism as well is found in other Lingis articles: (Lingis 2009b) and (Lingis 2012).

4 "The painfulness of pain, the malady or malignity of illness (mal), and, in the pure state, the very patience of corporeality, the pain of labor and ageing, are adversity itself, the against oneself that is in the self" (Levinas [1974] 2008, p. 51).

$5 \quad$ See (Cohen 2021).

\section{References}

Bernasconi, Robert. 1989. Rereading Totality and Infinity. In The Question of the Other: Essays in Contemporary Continental Philosophy. Edited by Arleen B. B. Dallery and Charles E. Scott. Albany: State University of New York Press, pp. 23-34.

Bernasconi, Robert. 2000. The Alterity of the Stranger and the Experience of the Alien. In The Face of the Other and the Trace of God: Essays on the Philosophy of Emmanuel Levinas. Edited by Jeffrey Bloechl. New York: Fordham University Press, pp. 62-89.

Burggraeve, Roger. 2002. The Wisdom of Love in the Service of Love: Emmanuel Levinas on Justice, Peace, and Human Rights. Translated by Jeffrey Bloechl. Milwaukee: Marquette University Press.

Burns, Lawrence. 2008. Identifying Concrete Ethical Demands in The Face oftThe Abstract Other: Emmanuel Levinas' Pragmatic Ethics. Philosophy E Social Criticism 34: 315-35.

Cohen, Richard A. 2016. Out of Control: Confrontations between Spinoza and Levinas. Ithaca: State University of New York Press.

Cohen, Richard A. 2021. Social Theory in Kant's Religion within the Limits of Reason Alone. International Philosophical Quarterly. forthcoming.

Critchley, Simon. 1999. The Ethics of Deconstruction: Derrida and Levinas. Edinburgh: Edinburgh University Library.

Henry, Michel. 2008. Material Phenomenology. New York: Fordham University Press. 
Levinas, Emmanuel. 2001. Existence and Existents. Translated by Alphonso Lingis. Pittsburgh: Duquesne University Press. First published 1947.

Levinas, Emmanuel. 2005. Time and the Other. Translated by Richard A. Cohen. Pittsburgh: Duquesne University Press. First published 1947.

Levinas, Emmanuel. 2007. Totality and Infinity: An Essay on Exteriority. Translated by Alphonso Lingis. Pittsburgh: Duquesne University Press. First published 1961.

Levinas, Emmanuel. 1990. Difficult Freedom: Essays on Judaism. Translated by Seán Hand. Baltimore: Johns Hopkins University Press. First published 1963.

Levinas, Emmanuel. 1994. Nine Talmudic Readings. Translated by Annette Aronowicz. Bloomington: Indiana University Press. First published 1968.

Levinas, Emmanuel. 2008. Otherwise than Being or Beyond Essence. Translated by Alphonso Lingis. Pittsburgh: Duquesne University Press. First published 1974.

Levinas, Emmanuel. 1987. Collected Philosophical Papers. Translated by Alphonso Lingis. Dordrecht and Boston: M. Nijhoff.

Levinas, Emmanuel. 1992. Ethics and Infinity: Conversations with Philippe Nemo. Translated by Richard A. Cohen. Pittsburgh: Duquesne University Press.

Levinas, Emmanuel. 1994. The Temptation of Temptation. In Nine Talmudic Readings. Translated by Annette Aronowicz. Bloomington: Indiana University Press, pp. 30-50.

Levinas, Emmanuel. 2001. Is it Righteous to Be?: Interviews with Emmanuel Levinas. Edited by Jill Robbins. Stanford: Stanford University Press.

Levinas, Emmanuel. 2003. Humanism of the Other. Translated by Nidra Poller. Urbana and Chicago: University of Illinois Press.

Lévinas, Emmanuel. 2003. On Escape = De L'évasion. Translated by Bettina Bergo. Stanford: Stanford University Press.

Lingis, Alphonso. 1996. Sensation: Intelligibility in Sensibility. Atlantic Highlands: Humanities Press.

Lingis, Alphonso. 1999. Objectivity and of Justice: A Critique of Emmanuel Levinas' Explanations. Continental Philosophy Review 32: 395-407. [CrossRef]

Lingis, Alphonso. 2004. Theoretical Paradox and Practical Dilemma. International Journal of Philosophical Studies 12: 21-28. [CrossRef]

Lingis, Alphonso. 2009a. Detotalization and Finitude. In A Century with Levinas: On the Ruins of Totality. Edited by Rita Šerpytytè. Vilnius: Vilnius University, pp. 161-71.

Lingis, Alphonso. 2009b. Three Objections to Levinas' Philosophy. Graduate Faculty Philosophy Journal 30: 189-95. [CrossRef]

Lingis, Alphonso. 2012. Six Problems in Levinas's Philosophy. PhaenEx 7: 30-40. [CrossRef]

Marion, Jean-Luc. 2005. From the Other to the Individual. Levinas Studies 1: 99-117. [CrossRef]

Mickūnas, Algis. 2011. Tarp filosofijos ir metafizikos (Emanuelis Levinas ir Alphonsas Lingis). Žmogus ir Žodis: Mokslo darbai. Filosofija 13: 5-12.

Nelson, Eric S. 2020. Levinas, Adorno, and the Ethics of the Material Other. Albany: State University of New York Press.

Sparrow, Tom. 2015. Plastic Bodies: Rebuilding Sensation after Phenomenology. London: Open Humanities Press.

Visker, Rudi. 2004. The Inhuman Condition. Looking for Difference after Levinas and Heidegger. New York, Boston, Dordrecht, London, and Moscow: Kluwer Academic Publishers. 